\title{
Profile of pharmaceutical care in primary health centers in São Bernardo do Campo, Southeastern Brazil
}

\author{
Rebeca Peres dos Santos Francisco e Silva ${ }^{1,2}$, \\ Francisco Winter dos Santos Figueiredo², Ricardo Peres do Souto ${ }^{2 *}$ \\ ${ }^{1}$ Secretaria de Saúde de São Bernardo do Campo (SSSBC), São Bernardo do \\ Campo, SP, Brasil, ${ }^{2}$ Centro Universitário FMABC, Santo André, SP, Brasil
}

\begin{abstract}
The effective insertion of the pharmacist into primary care is an important goal for health policies. The objective of this study was to describe and analyze pharmacists and Pharmaceutical Care in the primary health centers (UBS) of São Bernardo do Campo. Data were obtained through an interview applied to pharmacists. The instrument has three sections: (1) Pharmacist identification; (2) Pharmacist work; and (3) Pharmaceutical activities. Items in section 3 correspond to the guidelines of agencies that promote Pharmaceutical Care in the primary health system. All 24 pharmacists working in UBS in São Bernardo do Campo were interviewed. Every center dispensing medicines has a responsible pharmacist. These pharmacists are predominantly women and postgraduates. Activities of Pharmaceutical Care reported were: daily prescription analysis ( $75 \%$ of interviewees); monthly participation in patient groups (70.8\%); monthly follow-up of pharmacotherapy adherence $(58.3 \%)$; monthly participation in multiprofessional team meetings $(54.2 \%)$; monthly home visits $(12.5 \%)$; health education to the community (83.3\%); and pharmacist consultation (37.5\%). Frequency of prescription analysis and home visits was weakly associated with aspects of the pharmacist and the facility. This study showed that Pharmaceutical Services are structured in primary care in São Bernardo do Campo and many Pharmaceutical Care activities are offered in its UBS.
\end{abstract}

Keywords: Pharmaceutical services. Pharmaceutical care. Medication therapy management. Pharmacists. Primary health care. Public health system.

\section{INTRODUCTION}

The professional practice of the pharmacist has undergone major changes. In the last few decades, there has been a great shift towards actions closer to the users of the drugs (Hepler, Strand, 1990; Berenguer et al., 2004). This field of work for pharmacists has been designated Pharmaceutical Care and includes activities of patient education and guidance as well as supervision of the pharmacotherapy (Allemann et al., 2013). Pharmaceutical Care has become a strategic area within Pharmaceutical Services, a set of actions to promote, protect and recover health through access to medicines and their rational use (WHO, 2011). Proximity to the

*Correspondence: R. P. do Souto. Centro Universitário FMABC. Av. Lauro Gomes, 2000 - Vila Sacadura Cabral. Santo André/SP - CEP: 09060870 - Brasil. E-mail: ricardo.souto@fmabc.br. Conflict of interest: Nothing to declare. Source of financing: Nothing to declare pharmacist providing Pharmaceutical Care has been shown in randomized controlled trials to be beneficial to the patient, with favorable outcomes in several aspects related to disease control, health care and well-being (Babar et al., 2018). Interestingly, approaching the patient represents the recovery of a previous reality of the profession, preceding the industrialization of medicine production. At the beginning of the last century, in addition to preparing the drug, the pharmacist played a patient-oriented role in its use.

In Brazil, the same transformations within the pharmacist's scope are in process (Angonesi, Sevalho, 2010). These changes have occurred especially in the national public health system - Sistema Único de Saúde (SUS) - driven by government policies. Soon after the creation of SUS, the doors for the pharmacist's participation in primary health care were opened in 1998 with the national meeting Encontro Nacional de 
Assistência Farmacêutica and release of the guideline Política Nacional de Medicamentos (PNM) as an essential tool in public health (Pereira, Freitas, 2008). Then, in 2004 another guideline (Politica Nacional de Assistência Farmacêutica-PNAF) made Pharmaceutical Services an integral part of health policy and described more clearly the desired practices of Pharmaceutical Care (Oliveira, Assis, Barboni, 2010). With these regulations, the number of pharmacists attending in primary health centers (Unidades Básicas de Saúde - UBS) increased by $75 \%$ between 2008 and 2013, even though they represent only about $2 \%$ of health professionals (Carvalho et al., 2016).

The challenges of effectively inserting Pharmaceutical Care into SUS are great (Araújo et al., 2008). It is fundamental to improve the existing model and to continue seeking new strategies. For this reason, a major survey to characterize the pharmaceutical services offered in primary care was launched in 2015: Pesquisa Nacional sobre Acesso, Utilização e Promoção do Uso Racional de Medicamentos (PNAUM) - componente serviços (Álvares et al., 2017). The PNAUM survey obtained information from 300 municipalities in the country (all capitals and the largest cities in each region and randomly selected representatives from the smaller cities), interviewing city health managers, professionals responsible for delivering medicines at dispensing centers, and users of the health system. This is an important study for knowing and evaluating the general panorama of Pharmaceutical Care in the country. Nevertheless, it still needs to be complemented by research that details the clinical activities of pharmacists and explores local realities.

In addition to PNAUM, there are few studies that analyze pharmacists and pharmaceutical services in the Brazilian primary health network (Funchal-Witzel et al., 2011). For the most part, these articles describe logistic aspects of medicines and their dispensation (Naves, Silver, 2005; França Filho et al., 2008; Menolli, Ivama, Cordoni Júnior, 2009; Canabarro, Hahn, 2009; Silva Júnior, Nunes, 2012). Studies evaluating the activities of pharmacists directly with patients are less common and more recent (Obreli-Neto et al., 2015).

Considering the current changes in the pharmacist's role and the need for further evaluation of the pharmacist's presence and performance in general practice, the present study aims to describe and analyze the pharmacists and Pharmaceutical Care provided in primary health centers (UBS) in São Bernardo do Campo, São Paulo.

\section{METHOD}

\section{Place of study}

The study was carried out in São Bernardo do Campo, located in the metropolitan region of São Paulo, Southeastern Brazil. The estimated population in July 2017 was 827,437 inhabitants (IBGE, 2018). The city is divided into nine health territories, which are served by 34 primary health centers (UBS). These UBS are inserted in a variety of local contexts (urban and rural, high and low socioeconomic level), and reproduce many of the various scenarios of Pharmaceutical Care in Brazil. Only one of these facilities (UBS Jardim das Oliveiras) has no pharmacy, and the offer of pharmacy services occurs in another facility (UBS Orquídeas).

\section{Study outline}

This is a descriptive and quantitative analytical study of the characterization of Pharmaceutical Care professionals and activities in primary health care in São Bernardo do Campo. The data were obtained through a structured interview applied to all 24 pharmacists working in the UBS of the municipality.

\section{Instrument}

A form with direct, objective and closed multiple choice questions was proposed to be answered by pharmacists to monitor and evaluate their actions and activities regarding Pharmaceutical Care provided to UBS users under their responsibility.

The instrument is divided into three main sections: (1) Identification of the pharmacist; (2) Characterization of the pharmacist's work; and (3) Characterization of the activities performed in the pharmacy of the UBS.

The main variables evaluated in section 1 (Identification of the pharmacist) included information about the professional interviewed such as sex, graduation institution, time of graduation, and postgraduate qualifications. Regarding this last question, it was investigated whether the postgraduate degree was specialist, master's or doctor's and in which field. Among the fields of the postgraduation courses reported by pharmacists, Clinical Pharmacy and Hospital Pharmacy were considered specific to Pharmacy.

In section 2 (Characterization of the pharmacist's work), questions on the relation between the 
professional and the health center were included: type of contractual relationship, monthly workload, how long the pharmacist has been contracted, and whether the pharmacist works in another city besides São Bernardo do Campo. Inquiry was also made about the organizational issues of the health center such as the number of pharmacy assistants and dispensation of psychotropic drugs.

Section 3 (Characteristics of the pharmaceutical activities) corresponds to a survey of the activities of management of medicines and Pharmaceutical Care developed in the UBS, as well as the retrieval of information about medicines.

The items of medication management studied were: use of the standardized medication list adopted in the municipality; contribution to the regular review of the standardized list of drugs adopted in the municipality; place of drug dispensation; reception and storage of medicines; controls of medicine stock; verification of validity of the medicines.

Regarding medication information, the following were assessed: the frequency of doubts about medication; the proportion of resolution of these doubts; and sources of information consulted to clarify these doubts.

The items of Pharmaceutical Care evaluated corresponded to the recommendations and guidelines of several organizations that promote its insertion in the Brazilian primary health system. Eight documents were used (Chart 1). Based on these documents, the items evaluated were the frequency of: home visits, pharmaceutical consultations at the UBS, analysis of dispensed prescriptions, presence at multiprofessional health team meetings, participation in groups for followup and guidance to patients, monitoring of treatment adherence, involvement in health education actions for the community, and participation in programs for priority groups of Pharmaceutical Care (hypertension, diabetes mellitus, tuberculosis and smoking). Desired frequencies for each activity were arbitrarily defined considering the routine in the pharmacy from a UBS. In the case of prescription analysis, daily performance of this activity was considered adequate. In the case of participation in health team meetings, home visits, work in patient groups, and adherence monitoring, the appropriate frequency considered was at least once a month. In the case of pharmaceutical consultation, educational actions and performance in the priority groups (hypertension, diabetes mellitus, tuberculosis and smoking), just reporting the activity - even if occasionally (less than once a month) - was considered satisfactory.

The original instrument (in Portuguese) is available upon request to the authors.

\section{Data collection}

The study was conducted with the consent of the local authority (Departmento de Atenção Básica e Educação Permanente e Assistência Farmacêutica de São Bernardo do Campo).

The primary care pharmacists of São Bernardo do Campo were contacted individually at the Pharmaceutical Services meeting of the municipality or directly at the UBS. In the first appointment, the study was presented, and the free and informed consent term was signed. The instrument was applied in the month following the first contact, always by the same investigator. The participants themselves completed the form, and the investigator was available to clarify any doubts. In the case of pharmacists working in two UBS, only one form was filled out. Interviews were conducted between December 2017 and June 2018.

The number of registered inhabitants that use the UBS (active population) was extracted from the database of the municipal Health Department through the HygiaWeb information system. In the case of UBS sharing the same pharmacist, active populations were added.

\section{Ethical aspects}

The study was evaluated by the Research Ethics Committee of the Faculdade de Medicina do ABC and approved under process number 2,418,591.

\section{Statistical analysis}

Descriptive statistical analysis was performed by absolute and relative frequencies for qualitative variables, and by central tendency and dispersion measures for the quantitative variables, by adherence of the data to the normal distribution (evaluated by the Shapiro-Wilk test). Student's t-test and interval estimates of means (95\% confidence intervals) were used to analyze factors associated with non-prescription medications. The level of significance was 5\%. The statistical program used was Stata $^{\circledR}$ (StataCorp, LC) version 11.0. 
CHART 1 - Brazilian guidelines used for evaluating Pharmaceutical Care in primary health centers

AGENCY

DOCUMENT

Assistência Farmacêutica na Atenção Básica:

Instruções Técnicas para a sua Organização

Serviços Farmacêuticos na Atenção Básica à Saúde

Capacitação para Implantação dos Serviços

de Clínica Farmacêutica
REFERENCE

Brasil, 2006
Ministério da Saúde, Brazil

Ministério da Saúde, Brazil

Secretaria Municipal da

Saúde, São Paulo, Brazil
Manual de Assistência Farmacêutica. Rede de Atenção

Básica e de Especialidades. Descrição de Atribuições e

Atividades de Farmacêuticos e Técnicos de Farmácia

Brasil, 2014a

Brasil, 2014b

São Paulo, 2016

Conselho Nacional de

Secretários de Saúde, Brazil

Assistência Farmacêutica no SUS

Brasil, 2011

Conselho Federal de

Farmácia, Brazil

O Farmacêutico na Assistência Farmacêutica

do SUS: Diretrizes para Ação

CFF, 2015

Pan American Health

Organization

Consenso Brasileiro de Atenção Farmacêutica: Proposta

Ivama et al., 2002a

Pan American Health

Organization
Relatório 2001-2002: Atenção Farmacêutica

no Brasil: Trilhando Caminhos

\section{RESULTS}

Each of the 33 UBS of São Bernardo do Campo that offer pharmacy services has a professional pharmacist responsible for the sector. In 15 of these facilities, the pharmacist is exclusive. In other cases, one pharmacist attends two facilities. Therefore, a total of 24 pharmacists work in the public primary care of the municipality. None of these professionals works in the health network of another city besides São Bernardo do Campo. Two pharmacists are municipal statutory officials; the others are hired under the general Brazilian work regulation (Consolidação das Leis Trabalhistas). All have a monthly workload of 30 hours or more.

The characterization of pharmacists is shown in Table I. It can be observed that $75.0 \%$ are female. The mean age is 34.2 years and the average time since graduation is 7.8 years. The majority have a postgraduate degree $(75.0 \%)$, in almost all cases a specialist title. One of the participating pharmacists has completed a master's degree. Of the total number of professionals, for $29.2 \%$ the postgraduate degree was in a specific area of Pharmacy (Clinical Pharmacy or Hospital Pharmacy). Most pharmacists have been in the same workplace for a maximum of 4 years $(70.8 \%)$ and work in only one UBS $(62.5 \%)$

In relation to the pharmacies in the UBS of São Bernardo de Campo, it was verified that the average number of professionals working in the sector (pharmacists and assistants) was 3.4 per unit. The active population by UBS was, on average, 46,463 users. In most UBS (54.2\%) there is no dispensing of psychotropic drugs.

For medication management, all pharmacists interviewed reported receiving and storing medications, controlling the stock and checking their validity. All 
pharmacists use the standardized list of medicines adopted by the municipality, but only $45.8 \%$ contribute to its periodic review. Storage of part of the drugs outside the pharmacy, in places such as offices and service rooms, was reported in only one case. In most facilities, the dispensing of medicines occurs exclusively in the pharmacy of the unit.

Drug-related questions occurred at least once a week for $79.7 \%$ of pharmacists. These doubts were solved mainly by internet search $(83.3 \%$ of the cases), but rarely by accessing scientific databases such as PubMed/MEDLINE (4.2\% of cases). Consultations to pharmacist colleagues (16.7\%) and books (12.5\%) were also reported. The rate of resolution of doubts was $80-$ $100 \%$ for $91.7 \%$ of pharmacists; for the others it varied between $50 \%$ and $79 \%$.

Most pharmacists reported practicing the Pharmaceutical Care activities recommended in the scope of primary care (Table II). It is observed that the frequencies varied among activities. In each case, a minimum frequency that would be ideal for the activity was considered. Analysis of the prescriptions dispensed at the UBS should be performed daily, which was reported in $75 \%$ of cases. Regarding activities that should occur at least once a month, it was reported that: $70.8 \%$ reached this frequency for participation of follow-up and/or orientation groups for patients, $58.3 \%$ for follow-up of patients' adherence to treatment, $54.2 \%$ for attendance of health team meetings, and $12.5 \%$ for home visits. Finally, pharmaceutical consultations and the actions of education and health promotion to the community, more sporadic or uncommon activities, were reported (albeit less often than once a month), respectively, by $83.3 \%$ and $37.5 \%$ of pharmacists.

Next, it was studied whether there is an association between performance of the Pharmaceutical Care activities listed in Table II and the characteristics of the pharmacist and UBS. Considering the ideal frequencies chosen for each activity, no association with statistical significance was found. However, three relationships approached this situation: (1) pharmacists who had been at the UBS longer did more daily prescription analysis ( $\mathrm{p}=0.070$; Table III); (2) pharmacists working in a UBS with more professionals in the pharmacy carried out more monthly home visits $(\mathrm{p}=0.070$; Table IV); (3) pharmacists working in a UBS not dispensing psychotropic drugs carried out more monthly home visits $(p=0.089$; Table V).
The Pharmaceutical Care offered to four priority groups - those with hypertension, diabetes mellitus, tuberculosis and smoking - was also evaluated (Table VI).

Most UBS did not register hypertensive and diabetic patients who start disease control and treatment of the disease $(95.8 \%$ and $75.0 \%$, respectively). Regarding the follow-up of these patients, all services carried out dispensing and orientation of medications for the control and treatment of the diseases. In both programs, $62.5 \%$ of pharmacists participated in follow-up and/or counseling groups.

Registration of patients starting treatment for tuberculosis occurred in $62.5 \%$ of the services. Most offered guidance on the importance of treatment for tuberculosis $(58.3 \%)$ and following treatment adherence (75.0\%), but less than half supervised the daily intake of tuberculostatics (45.8\%).

Users with an interest in participating in the smoking control group were enrolled in $75.0 \%$ of the UBS. Most pharmacists (91.7\%) participated in the follow-up and/or orientation groups for participants of the National Tobacco Control Program and verified their presence in groups and adherence to treatment.

\section{DISCUSSION}

The present study evaluated the Pharmaceutical Care offered in primary care centers in the city of São Bernardo do Campo. For this, it was important to characterize the profile of the 24 pharmacists working at the UBS and to know the activities developed by these professionals with users and other professionals in the health team. The pharmacists were predominantly female and in the age group of 30 to 40 years, the same profile observed by the PNAUM survey for UBS pharmacists throughout the country (Araújo et al., 2017), as well as for professionals working in community pharmacies in the State of Santa Catarina (França Filho et al., 2008) and for pharmacists registered in the class council of the State of Paraná (Hipólito Júnior et al., 2017). The average time since graduation was similar to data from Paraná state (França Filho et al., 2008). The proportion of pharmacists in São Bernardo do Campo with a postgraduate degree was higher than in the other studies, where there was a variation of $32 \%$ to about $50 \%$ (França Filho et al., 2008; Araújo et al., 2017; Hipólito Júnior et al., 2017). Comparing the data over time, an increase in the proportion of postgraduate pharmacists may have occurred in the last 10 years. 
TABLE I - Characterization of the pharmacists working in primary health centers (UBS) of São Bernardo do Campo, SP

\begin{tabular}{|c|c|c|}
\hline \multicolumn{2}{|c|}{ VARIABLE } & $\begin{array}{c}\mathbf{N}(\%) \text { or } \\
\text { average } \pm \text { standard deviation }\end{array}$ \\
\hline \multirow{2}{*}{ Gender } & Male & $6(25.0 \%)$ \\
\hline & Female & $18(75.0 \%)$ \\
\hline \multicolumn{2}{|c|}{ Age } & $34.2 \pm 5.3$ years \\
\hline \multicolumn{2}{|c|}{ Time since graduation } & $7.8 \pm 3.7$ years \\
\hline \multirow{3}{*}{ Postgraduation } & No & $6(25.0 \%)$ \\
\hline & $\begin{array}{c}\text { Health Sciences } \\
\text { (except Pharmacy)* }\end{array}$ & $11(45.8 \%)$ \\
\hline & Pharmacy** & $7(29.2 \%)$ \\
\hline \multirow{2}{*}{ Time working in the UBS } & $\leq 4$ years & $17(70.8 \%)$ \\
\hline & $>4$ years & $7(29.2)$ \\
\hline \multirow{2}{*}{ Number of UBS working in } & 1 & $15(62.5 \%)$ \\
\hline & 2 & $9(37.5 \%)$ \\
\hline
\end{tabular}

* Collective Health, Public Health, Family Health. ** Clinical Pharmacy, Hospital Pharmacy.

TABLE II - Frequency of Pharmaceutical Care activities performed by pharmacists in primary health centers (UBS) of São Bernardo do Campo, SP

PHARMACEUTICAL CARE ACTIVITY

\section{FREQUENCY}

At least once a day At least once a month

Any frequency

\begin{tabular}{llll}
\hline Prescription analysis & $75.0 \%$ & $79.2 \%$ & $95.8 \%$ \\
\hline Patient group & $4.2 \%$ & $70.8 \%$ & $95.8 \%$ \\
\hline Follow adherence & $20.8 \%$ & $58.3 \%$ & $75.0 \%$ \\
\hline Health team meetings & $0.0 \%$ & $54.2 \%$ & $87.5 \%$ \\
\hline Education in health & $0.0 \%$ & $54.2 \%$ & $83.3 \%$ \\
\hline Home visit & $0.0 \%$ & $12.5 \%$ & $66.7 \%$ \\
\hline Pharmaceutical consultation & $4.2 \%$ & $20.8 \%$ & $37.5 \%$ \\
\hline
\end{tabular}


Profile of pharmaceutical care in primary health centers in São Bernardo do Campo, Southeastern Brazil

TABLE III - Association of pharmacists working time with the frequency of Pharmaceutical Care activities in the primary health centers (UBS) of São Bernardo do Campo, 2018

\section{PHARMACIST WORKING TIME AT UBS}

PHARMACEUTICAL CARE ACTIVITY
FREQUENCY

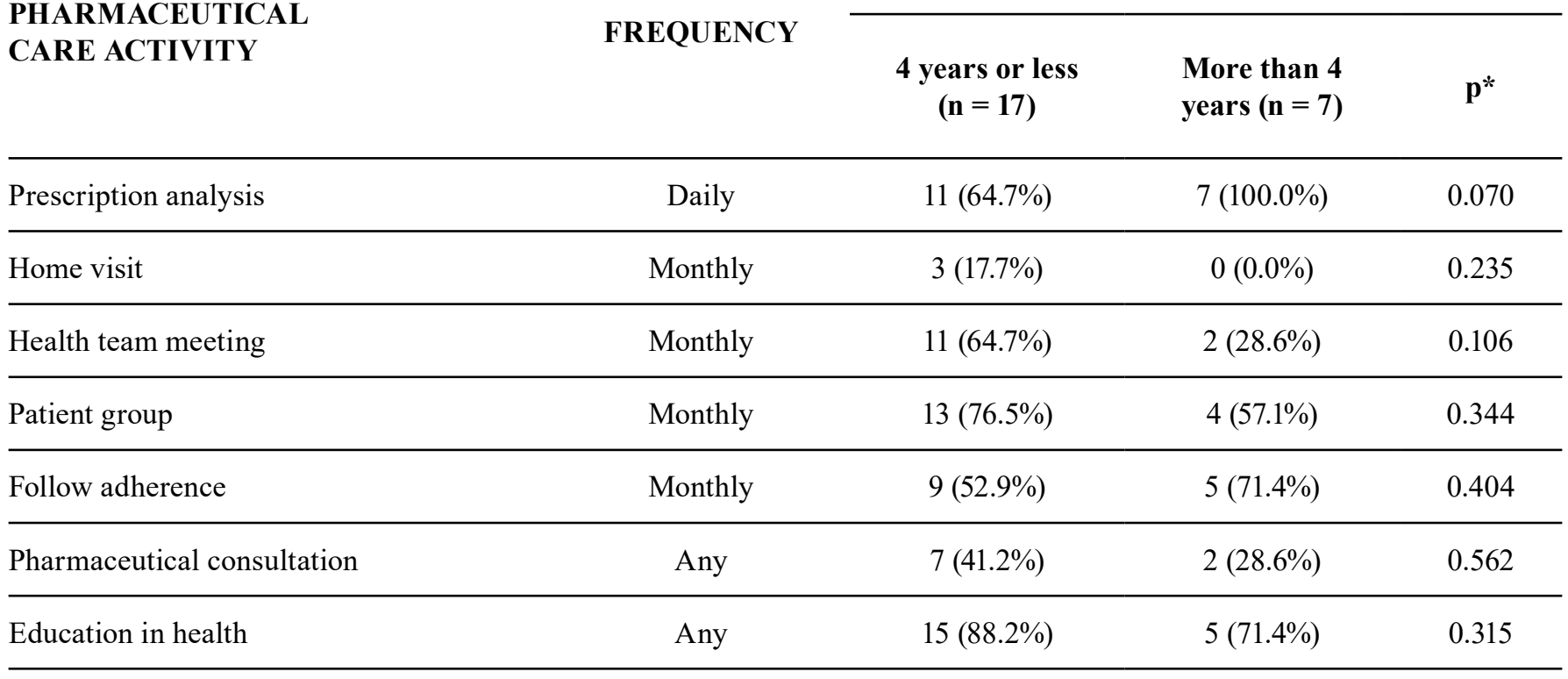

* Chi-square test.

TABLE IV - Association of the number of professionals in the pharmacy with the frequency of Pharmaceutical Care activities in the primary health center (UBS) of São Bernardo do Campo, 2018

\section{PHARMACEUTICAL CARE ACTIVITY}

FREQUENCY

NUMBER OF PROFESSIONALS average (IC 95\%)*

\section{Perform \\ Don't perform $\quad \mathbf{p}^{* *}$}

\begin{tabular}{|c|c|c|c|c|}
\hline Prescription analysis & Daily & $3.4(2.8-3.9)$ & $3.5(1.7-5.3)$ & 0.859 \\
\hline Home visit & Monthly & $4.7(1.6-10.9)$ & $3.2(2.8-3.7)$ & 0.070 \\
\hline Team meeting & Monthly & $3.6(2.9-4.4)$ & $3.2(2.3-4.1)$ & 0.421 \\
\hline Follows adherence & Monthly & $3.4(2.7-4.1)$ & $3.5(2.5-4.5)$ & 0.795 \\
\hline Pharmaceutical consultation & Any & $3.4(2.9-4.0)$ & $3.4(2.7-4.1)$ & 0.937 \\
\hline Education in health & Any & $3.4(2.8-3.8)$ & $3.8(0.2-7.3)$ & 0.581 \\
\hline
\end{tabular}


TABLE V - Association of dispensing of psychotropic drugs with the frequency of Pharmaceutical Care activities in the primary health center (UBS) of São Bernardo do Campo, 2018

\begin{tabular}{lcccc}
\hline & & \multicolumn{2}{c}{ DISPENSING OF } \\
PHARMACEUTICAL & FREQUENCY & PSYCTROPIC DRUGS \\
\cline { 3 - 5 } CARE ACTIVITY & & Yes (n= 11) & No (n =13) & $\mathbf{p}^{*}$ \\
\hline Prescription analysis & Daily & $9(81.8 \%)$ & $9(69.2 \%)$ & 0.478 \\
\hline Home visit & Monthly & $0(0.0 \%)$ & $3(23.1 \%)$ & 0.089 \\
\hline Team meeting & Monthly & $5(45.5 \%)$ & $8(61.5 \%)$ & 0.431 \\
\hline Patient group & Monthly & $6(54.6 \%)$ & $11(84.6 \%)$ & 0.106 \\
\hline Follows adherence & Monthly & $7(63.6 \%)$ & $7(53.9 \%)$ & 0.628 \\
\hline Pharmaceutical consultation & Any & $3(27.3 \%)$ & $6(46.2 \%)$ & 0.341 \\
\hline Education in health & Any & $8(72.7 \%)$ & $12(92.3 \%)$ & 0.200 \\
\hline
\end{tabular}

* Chi-square test.

TABLE VI - Pharmaceutical Care activities carried out in priority groups in primary health center (UBS) of São Bernardo do Campo, 2018

\section{PRIORITY GROUP}

QUESTION

Affirmative

answer (any

frequency)

\begin{tabular}{|c|c|c|}
\hline \multirow{3}{*}{ Hypertension } & $\begin{array}{l}\text { Do you dispense medications for the control and treatment of hypertension } \\
\text { advising patients on the importance of adherence to pharmacotherapy? }\end{array}$ & $100 \%$ \\
\hline & $\begin{array}{l}\text { Do you participate in follow-up and/or orientation } \\
\text { groups for patients with hypertension? }\end{array}$ & $62.5 \%$ \\
\hline & Do you register patients who start the control and treatment of hypertension? & $4.2 \%$ \\
\hline \multirow{4}{*}{ Diabetes mellitus } & $\begin{array}{l}\text { Do you dispense medications for the control and treatment of diabetes mellitus, } \\
\text { advising patients on the importance of adherence to pharmacotherapy? }\end{array}$ & $100 \%$ \\
\hline & $\begin{array}{l}\text { Do you advise patients on the start of glucometer use, } \\
\text { strips and materials needed for glycemic control? }\end{array}$ & $100 \%$ \\
\hline & $\begin{array}{l}\text { Do you participate in follow-up and/or counseling } \\
\text { groups for patients with diabetes mellitus? }\end{array}$ & $62.5 \%$ \\
\hline & $\begin{array}{l}\text { Do you register patients who start the control and treatment of diabetes mellitus } \\
\text { diseases, both those who use oral hypoglycemic agents and insulin users? }\end{array}$ & $25.0 \%$ \\
\hline
\end{tabular}


TABLE VI - Pharmaceutical Care activities carried out in priority groups in primary health center (UBS) of São Bernardo do Campo, 2018

PRIORITY GROUP

QUESTION
Affirmative

answer (any

frequency)

\begin{tabular}{lcc}
\hline & Do you follow patient adherence to treatment? & $75.0 \%$ \\
\cline { 2 - 3 } Tuberculosis & Do you register patients who start treatment for tuberculosis? & $62.5 \%$ \\
\cline { 2 - 3 } & $\begin{array}{c}\text { Do you advise patients on the importance of treatment } \\
\text { for the cure and success of pharmacotherapy? }\end{array}$ & $58.3 \%$ \\
\cline { 2 - 3 } Smoking & $\begin{array}{c}\text { Do you participate in monitoring and/or counseling groups } \\
\text { for users of the National Tobacco Control Program? }\end{array}$ & $45.8 \%$ \\
\hline \multirow{2}{*}{$\begin{array}{c}\text { Do you follow patient adherence to treatment and } \\
\text { participation in the tobacco control group? }\end{array}$} & $91.7 \%$ \\
\cline { 2 - 3 } & \multicolumn{2}{c}{ Do you register patients who want to be part of the smoking control group? } \\
\hline
\end{tabular}

In São Bernardo, all UBS dispensing medicines have a pharmacist responsible for the service. This is not typical in Brazil. PNAUM found only one pharmacist responsible for the dispensation for every three UBS in the country (Carvalho et al., 2017). In that survey, this responsibility lay most commonly with technicians or nursing assistants (43.0\%). Previous regional studies have found few or even no pharmacists in drug dispensing services from SUS (Naves, Silver, 2005; Canabarro, Hahn, 2009; Menolli, Ivama, Cordoni Júnior, 2009).

The occurrence of Pharmaceutical Care activities in the UBS of São Bernardo do Campo was high. Over $90 \%$ of pharmacists reported performing prescription analysis and participating in follow-up and guidance groups of patients. More than half reported engaging in health team meetings, conducting community health education, overseeing adherence to the treatment of patients, and visiting SUS users in their homes. The only activity performed by less than half of pharmacists was pharmaceutical consultation. For comparison, in PNAUM, the percentage of primary care pharmacists performing clinical activities was only $21.2 \%$ in the Southeast region and $21.3 \%$ in the whole country (Araújo et al., 2017). This divergence may be related in part to the lack of a precise definition of the clinical activities of a pharmacist. Participation in health team meetings, for example, was analyzed separately in PNAUM. In this topic, the national average was close to that observed in São Bernardo do Campo for the monthly participation in meetings of the health team (Araújo et al., 2017). Other similar indicators between PNAUM and this study included high participation in programs for the prevention and control of hypertension and diabetes (Araújo et al., 2017).

The proportion of pharmacists in São Bernardo do Campo who provided pharmaceutical consultation was very high $(37.5 \%)$, considering the scenario of Pharmaceutical Care in Brazil (Araújo et al., 2008). Pharmaceutical consultation is an activity recommended since the launch of the foundations of Pharmaceutical Care (Hepler, Strand, 1990). Unfortunately, its inclusion in primary health care has been a slow process, especially because of the existing paradigm that pharmacotherapy supervision is incumbent on doctors and nurses (Berenguer et al., 2004). Initiatives to include pharmaceutical consultation in SUS are sporadic, but the results are encouraging. As an example, a program including pharmaceutical consultations was able to improve the control of diabetes and hypertension, without increasing the costs of treatment (Obreli-Neto et al., 2015). 
Some aspects of pharmacists and UBS from São Bernardo were analyzed as factors in the occurrence of Pharmaceutical Care activities. No associations with statistical significance were found. It is possible, although unlikely, that the characteristics of the pharmacist (such as time since graduation and having a postgraduation degree) and the UBS (such as the ratio of the active population to the number of professionals working in the unit's pharmaceutical service) have no influence on the frequency of Pharmaceutical Care activities. But it is also admissible that the inability to detect any association has occurred because of the small sample size. Unfortunately, it is not possible to increase the number of interviewees, since all the primary care pharmacists of São Bernardo do Campo were included. For this reason, some trends are discussed below.

It was noticed that analysis of the prescriptions dispensed at UBS was more frequent among pharmacists who had been working in the facility for a longer time. In other words, greater experience of the pharmacist at the UBS, possibly including his or her familiarity with the service and the health care team, could create better conditions for the analysis of prescriptions. This activity aims to minimize problems related to the use of medications, identifying and correcting any mistakes and inaccuracies in prescription. It also allows optimization of the combination of drugs chosen, especially in cases of polypharmacy. Thus, prescription analysis is a tool that provides better outcomes in pharmacological treatment (Tan et al., 2014). In SUS, prescription analysis performed by a pharmacist can stimulate the use of the essential drug list, increase the number of prescriptions fully dispensed and reduce the number of drugs prescribed for patients with multiple prescriptions (Melo, Castro, 2017).

In relation to home visits by the pharmacist, two trends were verified. These visits occurred more frequently in UBS with more professionals in the pharmaceutical service and in UBS that do not dispense psychotropic drugs. In both cases, the availability of time to conduct out-of-unit visits seems to be the main issue. With more assistants and no need to worry about attributions related to the dispensing of controlled drugs, the pharmacist would have more time for home visits.

The insertion of pharmacists in the primary care system is an ongoing process across the world. Several recent studies describe experiences in all continents (see, for instance, Campbell, Braund, Morris, 2017;
Gillespie, Dolovich, Dahrouge, 2017; Gregório, Cavaco, Lapão, 2017). Comparison of results is not a simple task because of differences in the organization and operation of health systems. Benson et al. (2019) compiled a list of pharmacist activities in general practice from various countries. The study exposed the complexity of pharmacist contributions in primary care: 48 different competences were identified, and seven major categories were needed to organize them. The most common activity registered in this review was addressing adherence issues to pharmacological treatment. Pharmacists from São Bernardo were more involved in prescription analysis and patient groups. It is valuable to know what pharmacists are doing in primary care, for identification of successful initiatives to inspire putative new strategies and for improvement of the health system. Additionally, such information is needed for planning new curricula in Pharmacy education that includes the required competences for the future.

Perceptions of pharmacists concerning viability of Pharmaceutical Care in general practice are also informative. Pharmacists consider lack of time an important barrier for direct activities with patients (Eades, Ferguson, O'Carroll, 2011). Some support for that belief was found in São Bernardo. Preliminary evidence suggests that pharmacists with fewer assistants and more attributions are less available for activities beyond delivering medicines. A short time in the position may also be a negative factor. In this context, the conception of a "non-dispensing pharmacist" discussed in the literature is very opportune (Hazen et al., 2016). Released from more traditional responsibilities, those clinical pharmacists would focus all their actions on patients.

Among the limitations of this study may be mentioned: the small number of interviewees, the use of a novel instrument, and indirect evaluation of the Pharmaceutical Care activities through the reports of the pharmacists. Regarding the sample size, although reduced, all pharmacists in the municipality were studied. The instrument used is a form consisting of direct questions, drawn from recommendations found in official documents and regulations for Pharmaceutical Services and Pharmaceutical Care. Finally, indirect evaluation is the simplest and fastest way to simultaneously check various activities of pharmacists. Evaluation of the Pharmaceutical Services offered in SUS by the PNAUM survey was also based on reports (from managers, health professionals and users of the system). 
In conclusion, this study showed that Pharmaceutical Services are structured in primary care in São Bernardo do Campo and many activities of Pharmaceutical Care are offered in its UBS.

\section{REFERENCES}

Allemann SS, van Mil JW, Botermann L, Berger K, Griese N, Hersberger KE. Pharmaceutical care: the PCNE definition 2013. Int J Clin Pharm. 2014;36(3):544-55.

Álvares J, Alves MCGP, Escuder MML, Almeida AM, Izidoro JB, Guerra AA Junior, et al. National survey on access, use and promotion of rational use of medicines: methods. Rev Saude Publica. 2017;51(Suppl 2):4s.

Angonesi D, Sevalho G. Pharmaceutical care: conceptual and critical fundamentals for a Brazilian model. Ciênc Saúde Colet. 2010;15(Suppl 3):3603-14.

Araújo ALA, Pereira LRL, Ueta JM, Freitas O. Perfil da assistência farmacêutica na atenção primária do Sistema Único de Saúde. Ciênc Saúde Colet. 2008;13(Suppl.):611-7.

Araújo PS, Costa EA, Guerra AA Jr, Acurcio FA, Guibu IA, Álvares J, et al. Pharmaceutical care in Brazil's primary health care. Rev Saude Publica. 2017;51(Suppl 2):6s.

Babar ZU, Kousar R, Murtaza G, Azhar S, Khan SA, Curley L. Randomized controlled trials covering pharmaceutical care and medicines management: a systematic review of literature. Res Social Adm Pharm. 2018;14(6):521-39.

Benson H, Lucas C, Benrimoj SI, Williams KA. The development of a role description and competency map for pharmacists in an interprofessional care setting. Int J Clin Pharm. 2019;41(2):391-407.

Berenguer B, La Casa C, de la Matta MJ, Martín-Calero MJ. Pharmaceutical care: past, present and future. Curr Pharm Des. 2004;10(31):3931-46.

Brasil. Conselho Nacional de Secretários de Saúde. Assistência farmacêutica no SUS. Brasília: CONASS; 2011. Available from: http://bvsms.saude.gov.br/bvs/publicacoes/ colec_progestores_livro7.pdf

Brasil. Ministério da Saúde. Secretaria de Ciência, Tecnologia e Insumos Estratégicos. Cuidado farmacêutico na atenção básica. Caderno 1: serviços farmacêuticos na atenção básica à saúde. Brasília: Ministério da Saúde; 2014a. Avaliable from: http://bvsms.saude.gov.br/bvs/publicacoes/servicos_ farmaceuticos_atencao_basica_saude.pdf
Brasil. Ministério da Saúde. Secretaria de Ciência, Tecnologia e Insumos Estratégicos. Cuidado farmacêutico na atenção básica. Caderno 2: capacitação para implantação dos serviços de clínica farmacêutica. Brasília: Ministério da Saúde; 2014b. Avaliable from: http://bvsms.saude.gov.br/bvs/publicacoes/ cuidado_farmaceutico_atencao_basica_saude_2.pdf

Brasil. Ministério da Saúde. Secretaria de Políticas de Saúde. Departamento de Atenção Básica. Assistência farmacêutica na atenção básica: instruções técnicas para a sua organização. Brasília (DF): Ministério da Saúde; 2006. Avaliable from: http://www.ensp.fiocruz.br/portal-ensp/judicializacao/ pdfs/283.pdf

Campbell C, Braund R, Morris C. Beyond the four walls: an exploratory survey of location, employment and roles of pharmacists in primary health care. J Prim Health Care. 2017;9(4):297-310.

Canabarro IM, Hahn S. Panorama da assistência farmacêutica na saúde da família em município do interior do estado do Rio Grande do Sul. Epidemiol Serv Saúde. 2009;18(4):345-55.

Carvalho MN, Álvares J, Costa KS, Guerra AA J, Acurcio FA, Costa EA, et al. Workforce in the pharmaceutical services of the primary health care of SUS, Brazil. Rev Saude Publica. 2017;51(Suppl 2):16s.

Carvalho MN, Costa EMOD, Sakai MH, Gil CRR, Leite SN. Expansão e diversificação da força de trabalho de nível superior nas Unidades Básicas de Saúde no Brasil, 2008 2013. Saúde Debate. 2016;40(109):154-62.

Conselho Federal de Farmácia (CFF). O farmacêutico na assistência farmacêutica do SUS: diretrizes para ação. Brasília: CFF; 2015. Avaliable from: http://www.cff.org.br/ userfiles/file/livro.pdf

Eades CE, Ferguson JS, O'Carroll RE. Public health in community pharmacy: a systematic review of pharmacist and consumer views. BMC Public Health. 2011;11:582.

França Filho JB, Correr CJ, Rossignoli P, Melchiors AC, Fernández-Llimós F, Pontarolo R. Perfil dos farmacêuticos e farmácias em Santa Catarina: indicadores de estrutura e processo. Rev Bras Cienc Farm. 2008;44(1):105-13.

Funchal-Witzel MDR, Castro LLC, Romano-Lieber NS, Narvai PC. Brazilian scientific production on pharmaceutical care from 1990 to 2009. Braz J Pharm Sci. 2011;47(2):409-20.

Gillespie U, Dolovich L, Dahrouge S. Activities performed by pharmacists integrated in family health teams: results from a web-based survey. Can Pharm J (Ott). 2017;150(6):407-16. 
Gregório J, Cavaco AM, Lapão LV. How to best manage time interaction with patients? Community pharmacist workload and service provision analysis. Res Social Adm Pharm. 2017;13(1):133-47.

Hazen AC, Wal AW, Sloeserwij VM, Zwart DL, Gier JJ, Wit $\mathrm{NJ}$, et al. Controversy and consensus on a clinical pharmacist in primary care in the Netherlands. Int $\mathrm{J}$ Clin Pharm. 2016;38(5):1250-60.

Hepler CD, Strand LM. Opportunities and responsibilities in pharmaceutical care. Am J Hosp Pharm. 1990;47(3):533-43.

Hipólito Júnior E, Halila GC, Reis WCT, Guimarães MM, Guanaes LD, Pontarolo R, Correr CJ. Quality indicators of pharmacists' services in community pharmacies in Paraná State, Brazil. Braz J Pharm Sci. 2017;53(1):e16021.

Instituto Brasileiro de Geografia e Estatística (IBGE). IBGE Cidades. [accessed 2018 August 22]. Available from: https:// cidades.ibge.gov.br/brasil/sp/sao-bernardo-do-campo/ panorama

Ivama AM, Noblat L, Castro MS, Oliveira NVBV, Jaramillo NM, Rech N. Consenso Brasileiro de atenção farmacêutica: proposta. Brasília: Organização Pan-Americana da Saúde; 2002a. Avaliable from: http://bvsms.saude.gov.br/bvs/ publicacoes/PropostaConsensoAtenfar.pdf

Ivama AM, Noblat L, Castro MS, Oliveira NVBV, Jaramillo NM, Rech N. Relatório 2001-2002: atenção farmacêutica no Brasil: trilhando caminhos. Brasília: Organização PanAmericana da Saúde; 2002b. Avaliable from: https://www. paho.org/bra/index.php?option $=$ com docman\&view $=$ doc ument\&layout $=$ default\&alias $=790$-atencao-farmaceuticano-brasil-trilhando-caminhos-relatorio-2001-20020\&category_slug=vigilancia-sanitaria-959\&Itemid=965

Melo DO, Castro LLC. A contribuição do farmacêutico para a promoção do acesso e uso racional de medicamentos essenciais no SUS. Ciênc Saúde Colet. 2017;22(1):235-44.

Menolli PVS, Ivama AM, Cordoni Júnior A. Caracterización de los servicios farmacêuticos de atención primaria del Sistema Único de Salud en Londrina, Paraná, Brasil. Rev Panam Salud Pública. 2009;25(3):254-59.

Naves JO, Silver LD. Evaluation of pharmaceutical assistance in public primary care in Brasilia, Brazil. Rev Saude Publica. 2005;39(2):223-30.

Obreli-Neto PR, Marusic S, Guidoni CM, Baldoni Ade $\mathrm{O}$, Renovato RD, Pilger D, et al. Economic evaluation of a pharmaceutical care program for elderly diabetic and hypertensive patients in primary health care: a 36-month randomized controlled clinical trial. J Manag Care Spec Pharm. 2015;21(1):66-75.

Oliveira LCF, Assis MMA, Barboni AR. Assistência farmacêutica no Sistema Único de Saúde: da Política Nacional de Medicamentos à atenção básica à saúde. Ciênc Saúde Colet. 2010;15(Suppl 3):3561-7.

Pereira LRL, Freitas O. A evolução da Atenção Farmacêutica e a perspectiva para o Brasil. Rev Bras Cienc Farm. 2008;44(4):601-12.

São Paulo. Secretaria Municipal da Saúde. Manual de assistência farmacêutica. Rede de atenção básica e de especialidades. Descrição de atribuições e atividades de farmacêuticos e técnicos de farmácia. São Paulo: Secretaria Municipal da Saúde; 2016. Avaliable from: http://www.prefeitura.sp.gov.br/cidade/secretarias/upload/ ManualAssistenciaFarmaceutica.pdf

Silva Júnior EB, Nunes LMN. Avaliação da Assistência Farmacêutica na atenção primária no município de Petrolina (PE). Arq Bras Ciên Saúde. 2012;37(2):65-9.

Tan EC, Stewart K, Elliott RA, George J. Pharmacist services provided in general practice clinics: a systematic review and meta-analysis. Res Social Adm Pharm. 2014;10(4):608-22.

World Health Organization (WHO). The world medicines situation 2011, 3rd ed. Geneva: World Health Organization; 2011. Available from: http://who.int/medicines/areas/policy/ world_medicines_situation/en/index.html

Received for publication on $08^{\text {th }}$ January 2019 Accepted for publication on $06^{\text {th }}$ June 2019 